\title{
COVID 19: An Epidemiological and Host Genetics Appraisal
}

Sir,

The fast track Clinical Research Article ${ }^{1}$ (online publishahead-of-print 10 May 2020) measured and validated plasma concentration of ACE2 in two large and independent cohorts of men and women from European countries with heart failure according to the use of RAAS inhibitors and confirm that these are elderly patients that often have co-morbidities, including diabetes, hypertension, renal disease, and COPD. In both the cohort, they found plasma concentrations of ACE2 were higher in men than in women. According to the study, these data might explain the higher incidence and fatality rate of COVID-19 in men, but might not support previous reports suggesting that ACE inhibitors or ARBs increase the vulnerability for COVID-19 through increased plasma ACE2 concentrations. The fast track Clinical Research Article ${ }^{1}$ however, also discussed about ACE2 protein and its non-coding isoforms are highly expressed in the testis. Isoform transcription could possibly affect protein translation in this male-specific tissue which could partially explain the higher ACE2 protein concentrations and COVID-19 infection in men.

In this background, we ${ }^{2}$ reviewed (Published May 01, 2020) some earlier research published very recently with open access facilities before the publication of the above mentioned research article ${ }^{1}$ but, unfortunately not acknowledged by giving justice to worldwide painstaking researches and reviews, in the form of citing and mentioning in the reference section, which in turn might be a bit away from research publication ethics and academic fraternity as well.

The spike protein of SARS-CoV-2 had a strong binding affinity with ACE2 in human cell based on structural modelling and it is confirmed from previous studies, virus binds to the ACE-2 receptor in order to gain entry. Higher ACE2 expression level plays a major role in the spread of the infection, mainly by binding to ACE2 receptors in the lung. We mentioned a study who had reported more frequency of ACE2 in Asian men, considered as a reason for the higher prevalence of SARS-CoV-2 in this subgroup of patients than in women. ${ }^{3}$ In addition to that, another research reported significantly higher expression of basal
Access this article online

Website:

http://nepjol.info/index.php/AJMS

DOI: 10.3126/ajms.v11i5.29916

E-ISSN: 2091-0576

P-ISSN: $2467-9100$

Copyright (c) 2020 Asian Journal of Medical Sciences

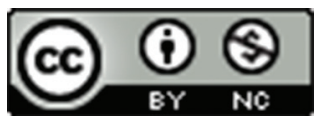

This work is licensed under a Creative Commons Attribution-NonCommercial 4.0 International License.

ACE2 in Asian females compared to males but indicating Asian females are more protected against SARS-CoV-2 infection rather than males, who are supposed to being more susceptible and morbid. They speculated that, SARS-CoV-2 infection decreases the level of ACE2 in both the males and females but this can be counteracted by higher basal ACE2 level in females but not in males because this higher basal ACE2 is inducible by higher sex hormone levels (Estrogen) which protect the females from this infectious disease even though they have the similar susceptibility like the male. ${ }^{4}$

We suggested ${ }^{2}$ and envisaged since, ACE2 is located on the $\mathrm{X}$-chromosome and this might cause circulating level of ACE2 to always be higher in men and X-inactivation mechanism in females give rise to the alternate expression of the two alleles which in turn guarantee a heterogeneous population of ACE2 molecules. Some of which might plays a protective role towards the infection if the $\mathrm{X}$-inactivation skewed towards the less SARS-CoV-2 binding prone allele, ${ }^{5}$ which means genetic heterogeneity of ACE2 molecule can modulate infection and disease progression.

Key words: Epidemiology; Gender difference; ACE2

Arup Ratan Bandyopadhyay, Diptendu Chatterjee, Kusum Ghosh, Pranabesh Sarkar

Department of Anthropology, University College of Science, University of Calcutta, 35, Ballygunge Circular Road, Kolkata - 700019, India 


\section{Address for Correspondence:} Prof. Arup Ratan Bandyopadhyay, Professor, Department of Anthropology, University College of Science, University of Calcutta, 35, Ballygunge Circular Road, Kolkata - 700019, India. Mobile: +91-9432316126.

E-mail: abanthro@caluniv.ac.in

\section{REFERENCES}

1. Sama IE, Ravera A, Santema BT, van Goor H, Ter Maaten JM, Cleland JGF, et al. Circulating plasma concentrations of angiotensin-converting enzyme 2 in men and women with heart failure and effects of renin-angiotensin-aldosterone inhibitors. European Heart Journal 2020; 41:1810-1817.

https://doi.org/10.1093/eurheartj/ehaa414

2. Bandyopadhyay AR, Chatterjee D, Ghosh K and Sarkar P. COVID 19: An Epidemiological and Host Genetics Appraisal.
Asian Journal of Medical Sciences 2020; 11(3): 71-76. https://doi.org/10.3126/ajms.v11i3.28569

3. Zhao Y, Zhao Z, Wang Y Zhou Y, Ma Y, Zuo W, et al. Singlecell RNA expression profiling of ACE2, the putative receptor of Wuhan 2019-nCoV. bioRxiv 2020; 1-13. https://doi.org/10.1101/2020.01.26.919985

4. Chen J, Jiang Q, Xia X, Liu K, Yu Z, Tao W, et al. Individual variation of the SARS-CoV2 receptor ACE2 gene expression and regulation. Aging Cell 2020; 00:e13168.

https://doi.org/10.1111/acel.13168

5. Elisa B, Rossella T, Ottavia S, Ciolfi A, Birolo G, Bruselles A, et al. ACE2 gene variants may underlie interindividual variability and susceptibility to COVID-19 in the Italian population. medRxiv 2020; 1-21.

https://doi.org/10.1101/2020.04.03.20047977

Authors Contribution:

Equal Contribution

Orcid ID:

Prof. Arup Ratan Bandyopadhyaya - (10 https://orcid.org/0000-0003-3119-0022

Source of Support: Nil, Conflict of Interest: None 